This is the post print version of the article, which has been published in Sociological Research

Online. 2016, 21(4) 4. http://www.socresonline.org.uk/21/4/4.html

Then down document has been downed from TamPub.uta.fi

a) The Insitutional Repository of University of Tampere

\title{
Justifications analysis: Understanding moral evaluations in public debates ${ }^{i}$ Tuomas Ylä-Anttila \& Eeva Luhtakallio*
}

Article published Nov 30, 2016 in Sociological Research Online

\section{Introduction}

The argument of this paper is that in public debates, over a wide variety of issues and across different political contexts, participants tend to justify their arguments using a relatively limited set of moral principles. They do this to rally potential supporters and convince potential opponents by envoking principles that are widely shared - although interpreted in varying ways - by the participants in the debate. Following Luc Boltanski and Laurent Thévenot, we outline a typology of these principles and show how they form the common basis for justifying arguments in debates over two very different issues (globalization and local politics) and two political contexts (Finland and France).

We make a contribution to two sociological literatures: the recently reinvigorated literature on the sociology of morality on the one hand, and the methodological literature on analyzing "framing" in textual material on the other. The empirical study of human morality - once presented as the core task of sociology by the likes of Emile Durkheim (1912; 1893) and Edward Westermarck (1908) - is experiencing a renaissance. Empirical studies on morality are now conducted by social psychologists (Haidt 2012), anthropologists (Robbins, 2012), political scientists (Abulof, 2013) and increasingly, again, by sociologists (Hitlin and Vaisey, 2010). In sociology, the most important development in this field is the emergence of the 'sociology of valuation and evaluation' (Lamont, 2011), on the rise in the US (eg Fourcade, 2011; Stark, 2009) and Europe (eg Adkins and Lury, 2011; Blokker, 2011). These recent approaches address morality through both theoretical currents and empirical

* The authors have contributed equally to this work. Direct correspondence to tuomas.yla-anttila@iki.fi or eeva.luhtakallio@uta.fi 
phenomena topical today, and connect the traditional sociological conceptions of morality to e.g. questions of justice, the world society, risk, work and family, economics, or the body (see Hitlin and Vaisey 2010).

Perhaps the most important discursive field where competing moral evaluations are presented in modern democracies is the mass media. Opposing political parties, interest groups, social movements and other political actors present competing claims, and justify them based on a set of moral principles. The participants in public debate need to provide legitimate answers for questions like "why is the problem you are addressing important" and "how does the solution you propose contribute to the common good", in short, justifications for their claims. The growing literature on moral sociology, however, has hardly looked at media texts, let alone presented a framework for systematically analyzing the use of moral principles of evaluation in the public sphere. Developing such methods is the aim of this paper.

The literature on the methodology of text analysis, on the other hand, has remained rather superficial with regard to the moral content in media texts. The concept most widely used for analyzing the grounds given for political claims in the public sphere is that of a "frame". Much work in sociology, political science and media studies has looked at how political actors frame their claims (Kriesi et al. 2012, 237-; Koopmans \& Statham 2010; Entman 1995). In this literature "moral frames", if present at all, play a marginal role. For example, according to one widely used definition, a moral frame is one that 'contains a moral message or makes a reference to morality, God and other religious tenets' (Neuman et al., 1992). Neuman et al. contrast moral frames with four other kinds of frames, namely, economic, responsibility, human interest and conflict frames. Studies using their framework tend to systematically find that moral frames are the least common kind, even when the 
topic of the debate analysed is one that could intuitively be thought of as "morally sensitive", such as asylum seekers or climate change (d'Haenens and de Lange, 2001; Dirikx and Gelders, 2010).

To arrive at a broader understanding of the moral content in public debates that contributes to the development of the sociology of morality, we draw on a foundational text in the field, De la justification by Luc Boltanski and Laurent Thévenot (1991). Following Boltanski and Thévenot, we argue that justifying a claim, say, in economic terms, also amounts to taking a moral stand. To say that policy option A should be chosen over B because it is more beneficial in economic terms is not just a neutral, practical statement (or a practical way of "framing" the claim). It amounts to taking the moral stand that money is a relevant measure of worth and ought to be priviledged when policies are evaluated.

This becomes especially evident in situations when monetary gain/loss is juxtaposed with some other measure of worth, such as equality. Some participants in a debate may argue that economic considerations should come first, while others may take the stand that equality, for example, in education or healthcare ought to be prioritized no matter what the cost in economic terms. This kind of conflict between economically justified arguments and those using equality justifications is, indeed, a moral conflict.

In this paper, we propose an analytical framework, Justifications Analysis (JA), that bridges the literatures on moral sociology on the one hand and "framing" political claims in the public sphere on the other. The need to work at the intersection of these two literatures arose during conversations we had while working on two independent studies, one on the globalization debate in the mass media in Finland (Ylä-Anttila 2010), and the other on local political disputes in France and Finland (Luhtakallio 2012). We were struck by the similarity of justificatory repertoires in these two 
very different issue fields and two political contexts. Differences, of course, existed, but it became clear they could be fruitfully understood in a broader framework of underlying similarities. That is, the differences were about combining and interpreting the same principles, rather than differences that would render the two issue fields and political contexts incommensurable. Inspired by these observations, we proceeded to organize a series of international workshops with the research group led by one of the two original developers of Justification Theory, Laurent Thévenot. The result of these workshops was the operationalization of our sociological intuition into the systematic analytical framework presented in this paper (see also Luhtakallio \& Ylä-Anttila 2011).

The paper proceeds as follows. First, we present the typology of moral justifications proposed by Boltanski and Thévenot and show how it can be operationalized to systematically analyze political claims in the public sphere. We then go on to demonstrate the usefulness of the method through two research examples, first on the globalization debate in Finland and then on local political conflicts in Finland and France. Finally, we discuss the usefulness and limits of JA, and its implications to the further development of the sociology of moral evaluations.

\section{From justification theory to analysing public debates}

Let us imagine a situation where city A announces that it is going to close down day care centre X. Parents whose children attend day care in this centre engage in a public struggle to save it from closing down. How can they justify their claims in public discussion? In what different ways can they argue that saving the centre serves the common good? Following Boltanski and Thévenot (1991), they have at their disposal at least the following seven principles of worthiness for building justifications for their arguments. These orders of worth - that all refer to the common good, 
although in different ways - are based on different philosophical foundations concerning moral worth.

Inspired worth. 'The children's creativity flourishes because the employees of the centre emphasize arts in the day care activities and create an inspiring atmosphere with their devoted approach to nursing'. The most well-known representation of inspired worth is St. Augustine's The City of God (1972[1470]), in which spiritual commitment, independence and indifference towards both market goods measured with money and personal dependencies are considered worthy. In addition to religious devotion, this conception of the common good can be embodied, for example, by an artist or an environmentalist inspired by the greatness of nature (Boltanski and Thévenot, 1991: 201).

Domestic worth. 'The day care centre has been the heart of the neighbourhood for decades and its leader is respected by the whole community'. An important philosophical formulation of domestic worth can be found in the works of the eighteenth-century French philosopher Bossuet (1967 [1709]) and is based on tradition, personal relationships, inherited status, intimacy and hierarchy. A paradigmatic worthy person is a patriarchal head of the house or a prince who rules his subjects accordingly. This principle is also deployed when an argument is based on a position in a hierarchic institutional structure (Boltanski and Thévenot, 1991: 207-208, 212, 215).

The worth of fame. 'The day care centre is well known and established by a famous, awardwinning paediatric.'. The worth of fame is drawn from Hobbes' Leviathan (1999 [1651]). The measure of worth is the recognition gained from as many followers as possible. Celebrities and opinion leaders are therefore worthy figures (Boltanski and Thévenot, 1991: 223-225). 
Civic worth. 'Children have the right to proper day care, and if this centre is closed down the children of the neighbourhood will be forced into an unequal position compared to other children in the city.' Civic worth is most clearly present in Jean-Jacque Rousseau's work The Social Contract (1997 [1762]). Solidarity, equality, the will of the people and collective wellbeing are ideas that invoke respect. Worthy persons are collectives, rather than individuals, and worthy things are mutually agreed conventions (Boltanski and Thévenot, 1991: 231-233, 237, 240).

Market worth. 'Day care organized in small units will cost less than in larger ones'. Market worth is sketched out by Adam Smith in his work The Wealth of Nations (1776). Worth is measured simply by money. Worthy persons are those who possess the most fortune, and worthy acts are the ones that promote the production of the most material goods. The common good is a byproduct of profit (Boltanski and Thévenot, 1991: 244-245, 250).

Industrial worth. 'The day care centre network has been designed by experts. It has been planned according to studies showing the benefits of small day care units to the development of the children's language capacities'. The industrial order of worth values efficiency, planning that leads to efficiency, regulation, and scientific expertise. Saint-Simon is the classic political philosopher whose work presents this order of worth at its purest. A typical worthy person in this world is a skilful engineer who can design systems that work efficiently. Equally important is the measuring and design of social processes (Boltanski and Thévenot, 1991: 252, 254, 259).

Ecological worth. 'If the day care centre is closed down, parents will have to take their children to day care at greater distance from their homes, often using their cars. This will increase pollution and accelerate climate change'. Ecological order of worth is a principle that gives intrinsic 
value to nature and the natural environment, as well as their protection and conservation (Lafaye and Thévenot, 1993).

These orders of worth form a relatively well institutionalized cultural toolkit for justifying claims in public debates ${ }^{\mathrm{ii}}$ by offering shared coordinates for actors, and therefore operating as means for reaching agreement. Thus, in any given non-violent conflict situation, all parties would be to some extent forced to acknowledge this variety of conceptions of common good, even if there was disagreement over which justification prevailed, or how. In the latter case, when the disagreement occurs within one order of worth, all parties agree on the criteria of justification, but disagree whether they are fulfilled. This is the case when, for example, actors agree that the procedure that produces (or saves) more money should be chosen out of two suggested procedures, but disagree on which one does; ie whether closing or keeping the famous day care centre is economically profitable to the city. In the case of two principles of worth clashing against each other, the conception of the common good based on one principle of justification is criticized according to criteria based on another; eg rather than the profitability of the day care centre, the basis of the decision should be the equal treatment of children living in different neighbourhoods.

One of the key features in working with JA is taking into account the relations of different orders of worth within one argument. Boltanski and Thévenot consider these relations as denouncing (dénonciation) and compromising (compromis) principles of justification. There are, however, other ways of combining or relating different justifications; for example, the fictional example above can also serve for a case of different justification principles operating as arguments for one and the same claim without directly influencing each other. 
In JA, the unit of analysis is a claim, an act made in public (cf. Koopmans and Statham, 1999). A claim can be a statement to the reporter, but also, for instance, a speech, a published report, a letter to the editor or a demonstration. Thus, a typical newspaper article contains numerous claims by different actors. Table 1 presents the coding of two claims from our two sets of research material. The first claim is reported as follows: 'Protestors from all around the world have arrived to Seattle, attempting to prevent the meeting of the World Trade Organization (WTO). In their view, WTO's free trade policy will increase economic inequality in the world' The second claims is reported as:'The tenants of the city of Helsinki worry about their rights. In their view, the city's plan to narrow tenants' rights to participate in negotiations will result in the city raising rents'. Justifications Analysis breaks the claims into the following elements:

Table 1. Coding a claim in Justifications Analysis

\begin{tabular}{|l|l|l|l|l|}
\hline Who: Speaker & To whom: Addressee & How: Means & What: Content & $\begin{array}{l}\text { Why: } \\
\text { Justification }\end{array}$ \\
\hline $\begin{array}{l}\text { 1: Civil society } \\
\text { organization/ } \\
\text { international }\end{array}$ & $\begin{array}{l}\text { 1: Intergovernmental } \\
\text { organization / } \\
\text { international }\end{array}$ & 1:Demonstration & $\begin{array}{l}\text { 1:WTO meeting } \\
\text { must be stopped }\end{array}$ & 1:Civic+ \\
Market - \\
$\begin{array}{l}\text { 2: Civil society } \\
\text { organization / } \\
\text { local }\end{array}$ & $\begin{array}{l}\text { 2: Political } \\
\text { establishment / local }\end{array}$ & 2: Statement & $\begin{array}{l}\text { 2: Tenants have } \\
\text { the right to } \\
\text { participate in } \\
\text { decision making } \\
\text { on rents }\end{array}$ & 2:Civic + \\
Market -
\end{tabular}

In JA, we code the claim makers (speakers) and addressees, as well as the means of claimsmaking and content of the claim. The core of the coding is the following three justification 
variables: the worth that a given claim refers to, whether the reference is positive or negative and the potential combinations of different justifications.

As is apparent by now, the most pronounced difference between the typical uses of "framing" as the basis for coding public debates and $\mathrm{JA}$ is that in the latter, the codes are not identified inductively from the data, but are based on a more or less fixed set of justification principles. Leaning on such relatively stable principles makes the approach particularly suitable for comparative research, as we will demonstrate in section 4, comparing Finland and France (see also Lamont and Thévenot 2000). Seen through the lens of JA, the public sphere is an arena of contestation between competing moral principles. Studying public debates from this point of view becomes an exercise in understanding the moral constitution of modern societies as much as dissecting the details of particular debates. With JA, the moral principles that guide different political actors and projects are brought to spotlight. Thus, we want to stress the importance of understanding the consequences of the tools used in social research. It is crucial to develop and deploy sociological tools capable of bringing to light the moral components of, for instance, economistic public talk that likes to portray itself as morally neutral.

\section{Research example: The globalization debate in Finland}

How do certain arguments become successful in media debates? In this section, we will show that Justifications Analysis can be useful in addressing this question. We argue that success can be achieved by justifying one's claims by invoking moral principles that are acceptable to potential allies and in some form, also to opponents. Thus, we look at three measures of success: (1) the salience of certain arguments and justifications, (2) the adoption of these arguments by a wide range of allies and (3) the acceptance of the arguments by potential opponents. 
The research material used to illustrate these points is a sample of newspaper articles on globalization in Finland between 1999 and 2005 ${ }^{\text {iii }}$. The mass media debate on globalization began with the challenge presented by the Global Justice Movement (GJM) that staged mass demonstrations and shut down the meeting of the World Trade Organization in Seattle in 1999. The activists forcefully made the claim that the current form of economic globalization results in prioritizing economic growth over just distribution and that the system of governing globalization is not organized according to democratic principles. These claims raise two kinds of civic justifications, those prioritizing equality and those prioritizing democracy, and denounce justifications that prioritize economic worth.

'The diverse NGOs... were all against the WTO's idea that trade will generate wellbeing to the whole world... The activists want to limit free flows of goods, money and people, referring, for example, to human rights and environmental norms.' HS 5.12.1999

These justifications proved to be strong enough to politicize the concept of globalization and start a debate over the kinds of moral values that current processes of economic globalization and current institutional structures for governing these processes, such as the WTO were advancing. The mentions of the word globalization in the news went from 16 per year on average between 19881998 to 150 in 1999 and 508 in 2005 - that is 1,4 times every day (see table 2).

Table 2 Frequency of the keyword globalization in the news, 1988-2005

\begin{tabular}{cc}
\hline Year & $\mathbf{N}$ \\
\hline \hline $1988-1998$ & $16^{*}$ \\
1999 & 150 \\
2000 & 255 \\
2001 & 417
\end{tabular}




\begin{tabular}{ll}
2002 & 297 \\
2003 & 223 \\
2004 & 458 \\
2005 & 508 \\
\hline
\end{tabular}

Moreover, globalization became a phenomenon that was mainly discussed in the light of its implications for justice and democracy, rather than, for example, its economic implications. Table 3 shows that 82 per cent of claims made about globalization in our sample were justified in civic terms, while only 55 per cent were justified in market terms. By our first measure, the salience of the issue of globalization and the share of civic justifications in the debate, the GJM and its arguments were successful.

Table 3. Share of claims using each justification, 1999-2005 (\%)

\begin{tabular}{lc}
\hline Justification & Share (\%)* \\
\hline \hline Domestic & 2 \\
Fame & 3 \\
Civic & 82 \\
Market & 55 \\
Industrial & 18 \\
Ecological & 10 \\
\hline N & 1217 \\
$*$ & The total shares add up to more than $100 \%$ because each claim can include several justifications
\end{tabular}

The arguments of the GJM and their justifications were also successful in a second sense: they were adopted by a significant number of influential political allies. But in order to achieve this success, the GJM activists had to adopt a wider repertoire of justifications. A simple denonciation of economic worth from the perspective of civic worth - saying that globalization of the economy is bad and globalization of justice and democracy is good - would not do. Instead, the main argument of the movement became that "to advance the common good, global markets need democratically 
agreed rules of the game". This argument is based on thinking that three orders of worth, economic (growth of the world economy), civic (democratic means of agreeing on the rules) and industrial (regulation based on scientific planning) can support each other.

This version of the argument for global justice and democracy was successful because it invoked a set of justifications that appealed to a wide range of political actors. A Green Party MP argued:

'Our aim is to create global rules of the game that curb the restless movements of capital and the unemployment and insecurity that are consequences of these movements' (HS, 26 September 1999).

These kinds of arguments also found some resonance in the Trade Unions, in Finland and internationally, and made their way to the very top of the political hierarchy. The President of the Republic, a Social Democrat, headed the International Labour Organization's World Commission on the Social Dimension of Globalization with the President of Tanzania, Benjamin Mkapa. The two presidents argued, in an op-ed on the publication day of the Commission's report:

'Just globalization requires building international institutions that represent the interests of all...We must prioritize sustainable economic growth...social goals and just rules of trade and finance. ' HS 25.2.2004

A particularly interesting variant of this type of argumentation was the idea of the so-called Tobin Tax, also known as the currency transaction tax. The idea was promoted by the French-born global justice organization Attac that became very successful in Finland upon its launch. The idea was to make global financial markets generate wealth for humanity (market justification) by 
establishing a democratically controlled institution (civic justification) that levies a cleverly engineered tax on currency transactions (industrial justification) and redistributes the wealth to development needs globally (civic justification). This combination of three justifications, as we have seen, was successful in itself in many ways. In addition to this winning combination, the success of the idea of the Tobin Tax was further helped by adding yet another kind of justification - that of fame. The tax was initially proposed in the 1970's by the economics Nobel Laureate, James Tobin. Not only was he a word famous authority on the financial markets, but also a mainstream neoclassical economist. His fame and scientific authority thus went far beyond the left wing social movement organizations that resurfaced his old idea.

In a poll in 2001, 70 per cent of MPs in Finland were in favor of the Tobin Tax (Ojala 2001). In 2015, quite some time after the resurfacing of the idea in the late 1990's, the European Union is in the process of adopting a version of the tax (Strupczewski 2015). The idea, thus, served as a discursive tool to the Global Justice Movement activists to draw mainstream attention to their other demands, but also succeeded in changing legislation.

Finally, the 'rules of the game' argument was also successful in the third sense of the term introduced above: it convinced not only allies but also many initial opponents. The acceptance of the idea of the Tobin Tax across party lines was one example of this. Another one was an op-ed by the Finnish representative of the International Chamber of Commerce, an organization very much in favor of the kind of free trade agreements that the GJM initially rose to oppose. For a while around the turn of the millennium, the acceptance of the rules of the game argument and its triple justification of market-civic-industrial, was so successful that even this former opponent felt the need to say: 
'Businesses do not want to see deregulation leading to savage markets...the liberalization of world trade must continue, but in an internationally regulated and controlled manner. The WTO and UN are examples of institutions which can develop common rules of the game.' (HS, 27 May 2001).

In sum, Justifications Analysis is useful for understanding why some arguments become successful in public debates. When political actors are willing and able to modify their arguments to lean on a wide enough range of moral justifications and thus resonate with a wide range of allies and sometimes opponents, they are more likely to succeed.

\section{Research example: Local disputes in Finland and France}

In our second research example, we analyse local disputes between citizens and city officials. The data consists of reports of such disputes in local newspapers in Helsinki and Lyon ${ }^{\text {iv }}$. Local newspapers have a particularly strong role in providing their readers with tools to imagine and reimagine the community they live in, and representing the 'common' in terms of disputes over the common good (cf. Thévenot 2006). Therefore, in order to understand the definition struggles concerning the common good comparatively, we asked what kind of disagreements attracted public attention, and how they were represented in these newspapers. Construction plans and sites, zoning, and different public services were common sources of conflict, but more explicitly value-laden topics like minority rights, interpretations of laws, and grounds for legitimate decision-making were also often debated. The themes of dispute also varied between the two contexts ${ }^{\mathrm{v}}$ : In Helsinki, the big issue at the time of the study were budgetary cuts targeted at the school network In Lyon, the foci were multiple. Some topics that attracted much attention were the installation of parking meters and abolition of free-of-charge parking, the living conditions and the right to education of the children of 
undocumented immigrants, and the repeated disappointments and difficulties met in the work of neighbourhood councils. The topics of dispute were, nevertheless, not the most captivating point of comparison. Instead, it was the ways in which different positions and opinions were justified in the local public spheres in Lyon and Helsinki.

When a group of parents in Finland opposed the city's plans to close down a local primary school, they claimed that the plan was based on inaccurate demographic statistics. When a group of residents in France opposed plans to install parking meters to their neighbourhood, they grounded their opposition in claiming that the city's plan was unjust and treated residents of different city districts unequally. Overall, the Finnish claim makers relied most willingly on arguments based on expertise, efficiency and scientific knowledge. The French claim makers counted most of all on argumentation based on equality, justice and solidarity. These justifications, based on industrial worth in the former case and civic worth in the latter, were the most prevalent in the articles dealing with local disputes. They also formed the central axis describing the differences between the Finnish and the French data.

Civic justifications appeared in their purest form in the claims of civic actors who stipulated the fulfilment of rights and democratic rules and laws, as illustrated in the following claim from the French data:

Demonstrators against assaults on the freedom of expression: The demonstrators protest against police violence, arbitrary arrests and abusive imprisonments in recent demonstrations, because these are attacks against the basic rights and liberty of expression (LP, May 19, 2005). 
The abovementioned protest built on the idea of shared democratic values and mutually agreed rules: police conduct was denounced solely on the basis that the freedom of speech and other basic rights cannot be neglected, as they are principles of high civic worth. It was not denounced, for instance, by insisting for more efficient training of crowd management in the police forces, which would have been an industrial justification.

Civic justifications were also recurrently combined with other justifications, a feature that brought up significant differences between the two contexts. In the Finnish context civic and industrial justifications were often combined, as in the following excerpt:

The teachers' union wants to clear out the legality of school policies in Vantaa. The local teachers' union insists that the legality (civic) of the planned cutbacks in schools have to be reexamined (industrial), and that the municipal council must further debate the matter (civic), because saving money through cutbacks leads to impossible working conditions for teachers (industrial), and possibly to practices violating the law on primary education (civic) (HS, April 27, 2005).

Industrial justifications were common in both contexts, but in the French data they were hardly ever used as the single justification, but rather in combination with others. In the Finnish data, in contrast, a citizen group could ground its claim solely on industrial worth and thus fully utilize the 'expert card', as in the example below:

The Finnish Nature Protection League and a local environmental association claim that the city's proposition of gasworks cannot be built as a power plant as planned, because recycling 
waste in this way turns it into an incineration plant, which requires the installation of specific types of filters (HS January 18, 2005).

Even though few citizen justifications deployed the industrial justification to this degree, references to statistics and scientific studies recurrently formed a central part of the argument in the Finnish data.

In the Finnish disputes, both citizens and city representatives eagerly invoked the industrial order of worth in their arguments. The same holds for civic worth in France. In the Finnish data, a quarter of the citizens' and almost half of the city representatives' justifications were industrial. Hence, both sides relied on justifications based on efficiency, quality and expertise. In the French data, more than a third of the citizens' and nearly half of the city representatives' justifications referred to civic worth. Common denominators were justifications based on law, civil rights, deliberation and solidarity. The industrial worth in Finland and the civic worth in France formed, respectively, the 'common ground' - an array of justifications that both sides of the dispute considered either right and suitable, or strategically reasonable, if not unavoidable.

This 'common ground' did not mean resolution or consensus. Instead, it produced what Boltanski and Thévenot call tests, in which the opponents argue on similar grounds. The following examples from the Finnish data illustrate this by way of a dispute portraying a compromise between industrial and market worth.

A: The representative of the municipal education department asked for constructive suggestions concerning the reduction of the number of schools - if the school spaces cannot be objects of cutbacks, something else will have to be cut, because as the number of pupils will 
decrease in the future (industrial), the price per capita (of primary education) cannot rise (market).

B: The citizens call for more clarity in the calculations (industrial) and actual need for saving (market), as the statistics and prognosis concerning the number of pupils are currently controversial (industrial) (HS March 9, 2005).

The citizens attempted, firstly, to prove the city representatives' industrial justification wrong by claiming that their calculations were based on inaccurate statistics, thus relying on the very same statistics instead of, for example, holding the city representatives accountable for trampling upon children's rights by referring to statistics. Secondly, the citizens questioned the market justification made by the city by calling for proof of this 'austerity argument'.

In the French data, disputes took a similar form, but often within the civic order of worth, testing its criteria:

Gerland and urban planning: the encounter of inhabitants and representatives

A: The inhabitants of Gerland demand that the decisions concerning the area's urban development have to be made in accordance with their demands, because in a democracy, the representatives must follow the will of the people, and listen to what they want, and the citizens' words have to be taken into account.

B: The councilor in charge states that a consensus has to be found, and that the councilors have to make the basic decisions after which the citizens can be consulted, because the councilors have been mandated for decision-making (LP April 21, 2005). 
The inhabitants appealed to general rules of democracy in justifying their claims about the plans - instead of, for example, relying on industrial justifications about efficiency and suitability of the plans for their district. In fact, their justification resembled a 'democratic governance check list', one not very concretely connected to the case at hand. The representative, on the other hand, questioned the inhabitants' interpretation of democracy, and used a civic justification to construct a claim for representative democracy.

The 'common ground' we observed in these local disputes leads us to reflect upon the impact of political culture: different justifications appear to be culturally successful in Finland and in France. Be it a library threatened of closing, or heavy savings targeted to preliminary schools, the Finnish mode of argumentation often treated these as questions of efficiency and technical expertise. Or, when they did appeal to civic justifications, they emphasized legality and contracts more than solidarity and rights. In the French data, civic worth had more amplitude, and justifications based on civic worth emphasized the aspects largely missing from the Finnish disputes.

In sum, using JA to analyse the local disputes helped us to discover the "toolkits" of local and national political cultures that everyone knows how to use, or at least understands to be essential in public debate. The different grounds of justification in the two contexts provided for different grounds of raising the level of generality, and politicizing. The civic justifications seemed to be closer to the arenas of politics altogether, whereas the technical facts the Finns argued about were sometimes neutralized to a point in which it seemed it was a mere misunderstanding between two experts whether a library should be closed or not. So, in the newspaper representation of local conflicts, the crucial conflicts resided in different worlds - in France, in the civic world, in Finland in the industrial world - making them very different conflicts with very different consequences 
altogether. The matter-of-fact, engineering-like industrial worth was the 'common ground' on which the parties of the Finnish local disputes understood each other the best, whereas the civic world with its groundings on solidarity, equality, and fairness were the most common 'meeting point' in the French conflicts - the city representatives used civic justifications even more abundantly than the citizens. This analysis drew portraits of 'the civic French', relying on solidarity-based justifications, and 'the industrial Finns', trusting in rational-functional justifications.

In both cases, however, the citizens seemed to be somewhat forced to justify on the shared grounds. The French were stuck with continuous 'reality tests' within the civic world, accused of being too domestic, or civic in a wrong way by their adversaries. The Finns were prone to back up even the strongest civic justifications with industrial 'facts', and however capable they were of expert argumentation they still were on the defense. Thus, in both cases, even if the citizens got their voices heard in the newspapers, they were the underdogs that had to try all possible arguments in order to convince the opposing party.

As for the implications of such analyses, they enable an in-depth discussion on the relationship between national political cultures and democracy, and therefore a comparison of the moral groundings of democratic practices and the opportunities for politicization. In other words, they tell not only about whether, but also about how does democracy work or fail in different contexts.

\section{Theoretical contributions to further development of the justification framework:}

\section{Subcategories and combinations}

Above, we have shown how justification theory can be operationalized to analyse public debates. Our empirical studies using this approach also point out possibilities to further develop the theory itself. The most central notions in this regard relate to, first, the possibilities of dividing and 
combining the orders of worth and, second, identifying power relations, and henceforth the contextual opportunities to open issues for politicization, and to succeed in bringing forth one's arguments in the public sphere, by asking who gets to define which of the orders are dominant.

Most methods of textual analysis, including several variants of discourse and frame analysis, derive their categories inductively from the research material. One typical example of the type of findings such studies tend to report are the 'five predominant frames' which 'emerge from the interactive relationship between social movements and the mass media' (Boykoff, 2006, 201). This is of course informative of the public debate - here the early protests of the Global Justice Movement - in question, but draws only a limited picture of what are the meanings and values at stake in the debate. What kind of moral evaluations lay behind the (supposedly journalist-led) frames Boykoff identifies $^{\mathrm{vi}}$ as the discursive forces delegitimizing the protesters' cause? And what about the protesters, what is worthy for them, why were they fighting this then seemingly desperate battle against global financial institutions? With JA, the battle of meanings that goes on in the public sphere is made evident, as the justifications of different actors are considered; not only the ones that "determine" the frame. Clearly, some party often dominates a public debate, but this is exactly why analysing the political and moral dimensions of the arguments is crucial. Hence, the analysis of what is going on in a public debate becomes more nuanced when (also the dominating) arguments are analysed as subject to tests between different moral values. Furthermore, with JA, sociological analysis avoids the risk of neutralizing the dominant discourse that is often portrayed as apolitical in mainstream public sphere, and instead, can fully incorporate the power dynamics of public debates (for a critique of the neglect of power in framing literature, see e.g. Carragee \& Roefs 2004). 
In contrast to mainstream inductive approaches to "framing", JA starts with the seven predefined categories of the justification theory. Perhaps the most important insight of the theory, based on Boltanski and Thévenot's empirical studies, is that people in everyday disputes and political conflicts in the public sphere tend to resort to a relatively limited number of moral principles, which have also been elaborated throughout the history of modern political philosophy. Beginning with this kind of relatively stable set of principles has the advantage that it encourages one to see how today's disputes are related to more general discussion about moral principles, much of which is repeated (and gradually evolves) over long periods of time. ${ }^{\text {vii }}$ Using a theoretically constructed set of categories has another advantage over approaches that draw the categories inductively from the research material: it enables comparisons between cases, be it countries or different public debates within the same country. If categories are drawn from the material by each case study separately, systematic comparison across cases is difficult and accumulation of knowledge about things such as political cultures is limited. Our approach presents one way of addressing these limitations.

Moreover, justifications analysis is by no means limited to looking for the occurrence of these seven categories in the data. Instead, Boltanski and Thévenot's original categories can be divided further as necessary, and their combinations are not limited to compromises and denunciations. The need to divide the orders of worth into subcategories came up in both of our case studies, especially regarding civic justifications. In the globalization debate civic claims were divided into democracy claims on the one hand, and equality claims on the other. In the local disputes it was clear that civic justifications were used in very different ways in Finland and in France.

In the globalization debate democracy justifications represent the procedural side of civic worth. According to arguments based on this type of justification, the biggest problem regarding 
globalization is that no democratic institutions exist for its governance. The other side of civic worth - arguments demanding a more equal distribution of income - focuses on the outcomes of globalization instead of governance procedures. The question is what consequences does globalization have for the distribution of income between and within countries, and for the mechanisms of taxation and redistribution.

Our second research example revealed important differences in the use of civic justifications in Finland and France. Whereas Finns emphasized laws and commonly agreed contracts when resorting to civic justifications, the French emphasized solidarity, equality between citizens and the significance of democratic participation. Regardless of this difference, the civic justifications in both countries clearly sprouted from the same root. By accounting for this variation in the use of civic justifications, we were able to deepen the results of our comparative analysis. The differences reflect the profoundly different conceptions held in the two political cultures about democracy, the collective understanding of the role of citizens and the different starting points of social bonds and solidarity (see Luhtakallio 2012). This observation describes the sensitivity of JA as a tool for comparative analysis. The method lends itself to examining cultural differences and similarities at different levels, from simple frequencies of the use of different justifications to delicate tones of cultural variations.

Another way to sensitize JA to the specificities of the data at hand is to focus on the different combinations of the orders of worth. Based on the two forms of combinations presented by Boltanski and Thévenot, compromise and denunciation, it is possible to form 42 pairs from the seven orders. When one includes cases where a compromise is formed between three orders of worth or where, for example, a compromise between two orders is denounced from the viewpoint of a third 
order, the number of possible combinations increases to hundreds. Moreover, both of our case studies revealed ways of combining justifications beyond denunciations and compromises.

Analysing the globalization debate, we found that two justifications are often combined by saying that one is a consequence of the other. In other words, it is claimed that the common good as defined in one order of worth automatically results from policies promoting the good as defined in another. Some participants in the globalization debate argued that promoting the market good automatically leads to an increase in civic good, while others had the opposite view of this relation. The first argument claims that markets produce democracy. In an op-ed dealing with China's membership in the WTO, this relationship is presented as something resembling a law of nature: 'Liberalization of the economy is always followed by demands for other rights' (HS November 25, 1999). According to this conception, China's WTO membership will eventually result in the collapse of the rule by a single party. Thus, the best way to promote democracy in China is to liberalize the economy. On rare occasions in the globalization debate, this idea about the relationship of civic and market worth is reversed. It is argued that redistribution of income does not hinder economic growth, as neoclassical economic theory would claim, but, to the contrary, promotes it. Such Keynesian thinking was very important in the building of Nordic welfare states, including Finland, beginning in the 1950s. In the 2000s, the number of Finnish actors making this argument is surprisingly low. But as it happens, the World Bank, criticized heavily by the GJM for its hostility to social policy, does take up this argument - perhaps as a reaction to the widespread criticism of its programs around the world. The main theme of the Bank's World Development Report 2005 is equality. A journalist summarizes the report as follows: 
The message of the report is simple: a good social and educational policy which provides equal possibilities for all, is also good economic policy. It makes possible the full use of the nation's resources, raises national economic productivity, and accelerates economic growth (HS September 22, 2005).

This example shows how JA helps in relating current public debates not only to the long history of political thought, but also to the more recent history of public debates about the same topic, increasing the potential for the accumulation of knowledge through linking several case studies that all use the same framework.

In the analysis of local disputes, we observed claims that combined orders of worth into more or less firm couplings. The couplings were combinations of justifications that did not alter the orders of worth, like in a compromise, or test their internecine supremacy, like in a denunciation-type combination. Citizen claim makers' use of coupling justifications was more frequent than city representatives'.

In the Finnish case, citizen claim makers justified their claims with a civic-industrial and/or market coupling so commonly that this combination rose to symbolize the ensemble of their claims. These couplings followed a fairly similar pattern in which the claim was justified with a coupling of justifications grounded, on the one hand, on laws and contracts, and on the other hand, on efficiency and quality and/or economy and savings. Civic justifications used by citizens seem 'natural': for example, in the case of a local tenant association demanding that the city should not change the code of tenement blocks because it would hamper resident democracy. In contrast, the frequent coupling of civic justifications with industrial and market ones raises the question whether this coupling is due to strategic necessity. The association also argued that a change in the code would hamper the 
efficient maintenance of the houses (industrial), and that resident democracy produces notable savings for the city in lower repair and maintenance costs (market). This form of coupling was recurrent in Finnish local disputes: citizens rarely justified their claims exclusively in terms of democracy, law or their rights as citizens, but almost always coupled their arguments with other types of worth, usually industrial or market.

Locating and interpreting the couplings helped us examine the question of power relations in the disputes. In Finland and France, the most recurrently deployed ways of justifying reflected not only cultural meaningfulness but also a degree of coercion, especially for the citizen claim makers who often had to settle for the terms of dispute - the orders of worth - set by the opposing party. Premises of justification theory include that everyone possesses the 'critical capacity' to use the orders of worth to justify claims, and that the orders are equal in the sense that claims invoking one order of worth are, in principle, as strong as those invoking any of the others. Our empirical analyses of public disputes raise the following question: how can these premises be fulfilled in empirical situations where the parties of the dispute are not equal in scope, resources or power potential? Another example from the Finnish data, with a citizen group justifying their claim with an industrialmarket coupling, illustrates the question: 'The inhabitants of Viberlaakso state that the district library has to be preserved, because its annual costs are not high, and its discontinuation would not bring the city big savings' (HS May 24, 2005).

The inhabitants' coupling of justifications to defend their library is startling. One can easily think of justifications based on civic worth in defence of a library, but instead, the inhabitants relied on the industrial worth to exhibit their expertise regarding the annual expenditure of public libraries and the scale of the city's budget, while also reinforcing their claim with the cold market fact that 
closing down the library would not amount to notable savings. In this coupled justification the power relations seem to affect the citizen claim makers: they operate within an agenda set by power holders.

In the French data, in contrast, justifications that seemed constrained appeared within the civic worth. Recurrently, a city representative would justify her/his position based on the principles of participatory democracy. The citizens opposing the claim then presented another civic justification - instead of, for example, uttering an industrial argument that the procedures of participatory democracy were dysfunctional. In Finland, the common ground seemed to be set by the bureaucratic rule of a political culture where citizens are not easily given the role of political actors, whereas in France, the rigid political hierarchy underlying the Republican rhetoric of egalitarian politics resulted in a somewhat uneasy coerciveness of the civic order of worth. As these examples illustrate, analysing different combinations of orders of worth and tracing recurrent features in these combinations makes it possible to develop the capacity of justification theory to take into account context specific power relations, and to shed light on how politicization processes occur, succeed, and fail. Understanding of the latter is of crucial importance in examining democratization and also multiple current challenges in "old” democracies (se Luhtakallio, 2012).

\section{Conclusions}

We have written this article with the conviction that the best way to present a research method is to show how it works. Hence, we introduced the JA by presenting its use in two empirical studies, highlighting the different possibilities of data, scope and measure of analysis, as well as the axes of interpretation the method opens. Analyzing the globalization debate in Finland, we argued that arguments are more likely to become successful in the public sphere if they are supported by a 
broad set of justifications, appealing to a wide range of potential allies and accepted, to some extent, by potential opponents. Comparing Finnish and French local disputes, we found that in the former, both citizens and the decision makers resort to industrial justifications, emphasizing efficiency and expertise. In the latter, the civic worth provides a similar 'common ground' for justifying public claims, emphasizing civil rights, deliberative procedures and solidarity.

We have presented Boltanski and Thévenot's classification of seven orders of worth as one possible way of recognizing and understanding the moral dimension of conflicts in the public sphere - often left in the margins by conventional approaches to the study of framing. There is, of course, no reason to assume that the number of relevant categories should be limited to seven. Furthermore, as we have noted, it is important to proceed with caution with regard to the sensitivity of the framework towards non-Western cultural traits.

This categorization, however, does have roots running through Western moral philosophy and is, consequently, widely recognized and utilized by a range of political actors across different settings. This, we have argued, makes the framework particularly suitable for comparisons between different debates, time periods and national contexts. If, on the one hand, systematic differences are found in the use of justifications across different debates within the same national context, relatively robust conclusions about persistent traits of political culture in that context can be drawn. If, on the other hand, ways of justifying arguments are found that form common ground across national political cultures, this opens the way to better understanding the possibilities of global public deliberation. 
'We'd like to thank Laurent Thévenot, Risto Alapuro, Markku Lonkila, Veikko Eranti, Anna Kukkonen, Tomi Lehtimäki, Tuukka Ylä-Anttila, and other members of the Helsinki Research Group for Political Sociology, the three anonymous reviewers and all other colleagues who have given feedback on earlier versions of this work on a number of occasions.

ii This applies at least in the context of mediated public spheres of modern democracies. The extent to which moral talk even in these special circumstances is limited to the framework described by the seven orders of worth is, of course, an important question. We see this as an empirical question and point out ways to make the framework more flexible through our research examples in section 5.

iii The data was selected through two-phase purposive sampling. First, nine key events in the debate, marked by peaks in the occurrence of the word 'globalization', were selected. Second, a qualitative reading of a part of the sample was used to generate a wider set of keywords referring to institutions (such as 'WTO', 'G8'), phenomena (such as 'trade', 'liberalization') and event locations (such as 'Genoa') associated with globalization, to capture also articles that discussed globalization withouth using the term itself. The newspaper's online archive was then searched with this set of keywords for a period of one week before and three weeks after each event. This resulted in a sample of 491 articles in which a total of 717 claims were presented. The data include different types of articles: news reports, opinion pieces, and editorials.

\footnotetext{
iv The data was collected from the newspapers Helsingin Sanomat (HS) and Le Progrès (LP) between January and
} June in 2005. It comprised 198 articles and 267 claims (Finland $n=140$, France $n=127$ ). Due to the different scope of the two newspapers, and in order to collect a comparable sample of notably local disputes, the Finnish data was collected only from the 'City' section of Helsingin Sanomat that concentrates only on the Helsinki region, while Le Progrès was covered in its entirety (Luhtakallio, 2012, 198). The data includes all articles (only reportage and news articles written by journalists were included, as opinions and editorials did not exist in the French data source) that concerned local conflict issues participatory democracy, social movement actions addressing the city, encounters, deliberations, disagreements - and included an exchange between citizens (individuals or groups) and representatives of the city (politicians, office holders, mayors, spokespersons of municipal/regional institutions) (Luhtakallio, 2012, 198-199). The articles were collected by 
using both digital and manual archives (microfilmed in the case of Helsingin Sanomat, bound in the case of Le Progrès). The digital archives were searched with a set of keywords related to local issues and participation (see Luhtakallio, 2012, 217), and the analogical archives were read through at the level of titles.

v For more details on the comparison of the two newspapers and the two cities, see Luhtakallio, 2012, 16-19, 196-201.

vi The frames identified by Boykoff were the Violence Frame, the Disruption Frame, the Freak Frame, the Ignorance Frame, and the Amalgam of Grievances Frame (Boykoff 2006, 211).

vii Indeed, the suggestions of the exploration worth and the project worth have been put forward (Auray and Vétel 2013; Boltanski and Chiapello 1999). These have not been included in our framework for reasons inherent to the critical debate about the justification theory: both suggestions are, in different ways, 'special cases' that do not quite follow the same pattern as the original six. However, the seventh, the ecological worth, does follow the same pattern in our reading (Lafaye and Thévenot 1993, for an extensive debate see Blok 2013). 


\section{Literature}

Abulof, U (2013) 'Normative concepts analysis: unpacking the language of legitimation', International Journal of Social Research Methodology, Vol. 18, No. 1, p. 73-89.

Adkins, L and Lury, C (eds.) (2011) 'Special Issue: Measure and Value’. The Sociological Review Vol. 59, Supplement s2.

Augustine (1972[1470]), City of God. Trans. by Henry Bettenson. Hammondsworth: Penguin Books.

Auray, N and Vétel B (2013) 'L'exploration comme modalité d'ouverture attentionnelle: le cas d'un jeu freemium', Réseaux No. 182, p. 153-186.

Blok, A (2013) 'Pragmatic sociology as political ecology. On the many worths of nature(s)', European Journal of Social Theory, Vol. 16, No. 4, p. 492-510.

Blok, A (2015) 'Attachments to the common-place: pragmatic sociology and the aesthetic cosmopolitics of eco-house design in Kyoto, Japan', European Journal of Cultural and Political Sociology, in press.

Blokker, P (2011) 'Introduction to the special issue. Pragmatic sociology: Theoretical evolvement and practical application'. European Journal of Social Theory Vol. 14, No. 3, p. 251-261.

Boltanski, L and Chiapello E (1999) Le nouvel esprit du capitalism. Paris: Gallimard.

Boltanski, L and Thévenot, L (1999) 'The sociology of critical capacity', European Journal of Social Theory Vol. 2, No. 3, p. 359-377.

Boltanski, L and Thévenot, L (1991) De la justification. Les Economies de la Grandeur. Paris: Gallimard.

* The authors have contributed equally to this work. Direct correspondence to tuomas.yla-anttila@iki.fi or eeva.luhtakallio@uta.fi 
Borgh, V (2011) 'One-way Europe? Institutional guidelines, emerging regimes of justification, and paradoxical turns in European welfare capitalism', European Journal of Social Theory Vol. 14 No. 3, p. 321-341.

Bossuet, J B (1967 [1709]) Politique tireé des propres paroles de l'Écriture sainte. Geneve: Droz.

Boykoff, J (2006) 'Framing dissent: Mass-media coverage of the global justice movement', New Political Science Vol. 28, No. 2, p. 201-28.

Camus-Vigué, A (2000) 'Community and civic culture: the Rotary Club in France and the United States', in Lamont. M and Thévenot, L (eds.) (2000) Retbinking Comparative Cultural Sociology: Repertoires of Evaluation in France and the United States. Cambridge: Cambridge University Press, p. 213-228.

Carragee, K M, and Roefs, W (2004) 'The neglect of power in recent framing research', Journal of communication Vol. 54, No. 2, p. 214-233.

Centemeri, L (2011) 'Retour à Seveso La complexité morale et politique du dommage à l'environnement', Annales. Histoire, Sciences Sociales Vol. 66, No.1, p. 213-240.

Centemeri, L (2015) 'Reframing Problems of Incommensurability in Environmental Conflicts Through Pragmatic Sociology: From Value Pluralism to the Plurality of Modes of Engagement with the Environment', Environmental V alues, Vol. 24, No. 3, p. 299$320(22)$.

d' Haenens, L and de Lange, M (2001) 'Framing of asylum seekers in Dutch regional newspapers', Media, culture and society, Vol. 23, No. 6, p. 847-860. 
Dirikx, A and Gelders, D (2010) 'To frame is to explain: a deductive frame-analysis of Dutch and French climate change coverage during the annual UN conferences of the parties', Public understanding of science Vol. 19, No. 6, p. 732-742.

Durkheim, E (1912) Les formes élémentaires de la vie religieuse. Paris: Presses Universitaires de France.

Durkheim, E (1893) De la division du travail social. Paris: Presses Universitaires de France.

Entman, R M (1993) 'Framing: toward clarification of a fractured paradigm', Journal of Communication Vol. 43, No. 4, p. 51-8.

Fahmy, S (2010) 'Contrasting visual frames of our times: A framing analysis of English- and Arabic language press coverage of war and terrorism', International Communication Gazette, Vol. 72, No. 8, p. 695-71.

Fourcade M (2011) 'Cents and sensibility: economic valuation and the nature of 'nature.' American Journal of Sociology, Vol. 116, No. 6, p. 1721-77.

Haidt, J (2012) The righteous mind: Why good people are divided by politics and religion. New York: Pantheon.

Hitlin, S and Vaisey, S (2010) Handbook of sociology of morality. New York: Springer.

Hobbes, T (1894[1651]) Leviathan; or, the matter, form, and power of a commonwealth ecclesiastical and civil. London, Glasgow and New York: G. Routledge and Sons.

Jagd, S (2011) 'Pragmatic sociology and competing orders of worth in organizations', European Journal of Social Theory Vol. 14, No. 3, p. 343-359. 
Keane, J (1995) 'Structural transformations of the public sphere', The Communication Review Vol. 1, No. 1, p. 1-22.

Koopmans, R, \& Statham, P (Eds.) (2010) The making of a European public sphere: Media discourse and political contention. Cambridge University Press.

Kriesi, H, Grande, E, Dolezal, M, Helbling, M, Höglinger, D, Hutter, S, \& Wüest, B (2012) Political conflict in western Europe. Cambridge University Press.

Lafaye, C and Thévenot, L (1993) 'Une justification écologique? Conflits dans l'aménagement de la nature', Revue Française de Sociologie, Vol. 34, No. 4, p. 495-524.

Lamont. M and Thévenot, L (eds.) (2000) Rethinking Comparative Cultural Sociology: Repertoires of Evaluation in France and the United States. Cambridge: Cambridge University Press.

Lamont, M (2000) 'The rhetorics of racism and anti-racism in France and the United States', in Lamont. M and Thévenot, L (eds.) (2000) Rethinking Comparative Cultural Sociology: Repertoires of Evaluation in France and the United States. Cambridge: Cambridge University Press, p. 25-55.

Lehtonen, T-K and Liukko, J (2010) 'Justifications for commodified security: The promotion of private life insurance in Finland 1945-90', Acta Sociologica Vol. 53, No. 4, p. 371-386.

Luhtakallio, E (2012) Practicing Democracy. Local Activism and Politics in France and Finland. Basingstoke: Palgrave Macmillan. 
Luhtakallio, E and Ylä-Anttila, T (2011) 'Julkisen oikeuttamisen analyysi sosiologisena tutkimusmenetelmänä.' [Public justification analysis as a sociological tool] Sosiologia 48: $1,34-51$

Margolis, E (1999) 'Class pictures: Representations of race, gender and ability in a century of school photography', Visual Studies, Vol. 14, No. 1, p. 7-38.

Morreale, J (1991) A new beginning. A textual frame analysis of the political campaign film. Albany: State University of New York Press.

Neuman, W, Just, M and Crigler, A (1992) Common knowledge: News and the construction of political meaning. Chicago: University of Chicago Press.

Ojala, M (2001) 'Eduskunta Tobinin veron puolella' In https://www.kepa.fi/uutiset/1837 Accessed May 26, 2016.

Robbins, J (2012) 'On becoming ethical subjects: Freedom, constraint, and the anthropology of morality', Anthropology of This Century Vol. 5. http://aotcpress.com/articles/ethicalsubjects-freedom-constraint-anthropology-morality/.

Rousseau, J J (1762) Du Contrat Social ou Principes du droit politique. Marc-Michel Rey, Amsterdam.

Sen, A (2010) The idea of justice. London and New York: Penguin Books.

Smith, A (1776) An inquiry into the nature and causes of the wealth of nations. London: Strahan and Cadell.

Snow, D A and Benford, R (1988) 'Ideology, frame resonance, and participant mobilization', International Social Movements Research Vol.1, p. 197-218. 
Stark, D (2009) The Sense of Dissonance. Princeton, NJ: Princeton University Press.

Strupczewski, J (2015) Ten EU countries agree on aspects of a financial-transaction tax. , accessed May 26, 2016.

Thévenot, L (2006) L'action au pluriel. Sociologie des régimes d'engagement. Paris: Editions La Découverte.

Thévenot, L (2007) 'The plurality of cognitive formats and engagements: Moving between the familiar and the public', European Journal of Social Theory, Vol.10, No. 3, p. 409-423.

Thévenot, L (2014) 'Voicing concern and difference: From public spaces to common-places', European Journal of Cultural and Political Sociology, Vol. 1, No 1, p. 7-34.

Thévenot, L, Moody, M and Ladaye, C (2000) 'Forms of valuing nature: arguments and modes of justification in French and American environmental disputes' in Lamont. M and Thévenot, L (eds.) (2000) Rethinking Comparative Cultural Sociology: Repertoires of Evaluation in France and the United States. Cambridge: Cambridge University Press, p. 229-272.

Westermarck, E (1908) Suicide: a chapter in comparative ethics. The Sociological Review Vol. 1, No 1, p. $12-33$ 